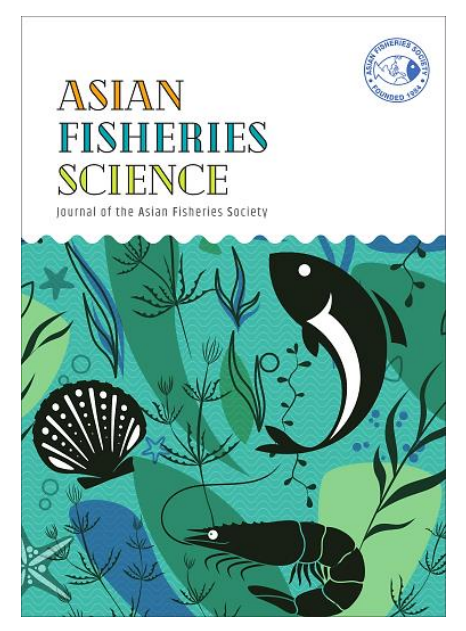

\title{
Influence of Nitrogen Cycle Bacteria on Nitrogen Mineralisation, Water Quality and Productivity of Freshwater Fish Pond: A Review
}

\author{
IPSITA PAUL', ASHIS KUMAR PANIGRAHI', SUBHENDU DATTA ${ }^{2, *}$ \\ 'Department of Zoology, Faculty of Science, Eco-Toxicology, Fisheries \& Aquaculture Extension Laboratory, University of Kalyani, \\ Kalyani 741235, West Bengal, India
}

${ }^{2}$ Regional Research Station, Bidhan Chandra Krishi Viswavidyalaya, New Alluvial Zone, Gayeshpur, Nadia 741234, West Bengal, India

*E-mail: drsubhendudatta@rediffmail.com | Received: 31/10/2019; Accepted: 11/06/2020

(C)Asian Fisheries Society

ISSN: 0116-6514

E-ISSN: 2073-3720

https://doi.org/10.33997/j.afs.2020.33.2.006

\begin{abstract}
Nitrogen is one of the prime influential macronutrients which directly stimulate the productivity of pond ecosystems. The steps involving chemical transformations of nitrogen bound in complex organic matters are dominated by a variety of nitrogen cycle bacteria responsible for mineralisation of organic nitrogen into inorganic forms. Application of excess nitrogen in the form of fertiliser may cause deterioration of water quality by accumulation of toxic nitrogenous compounds such as ammonia and nitrite. Over-stimulation of nitrogen beyond a pond's assimilatory capacity may be detrimental to the aquatic organisms and needs special attention to keep water quality conducive for fish growth. Seasonal variations of physicochemical parameters of water and sediments directly influence the nitrogen cycle through population dynamics of nitrogen cycle bacteria. Potentials of surplus nitrogen deportation by denitrifiers create opportunities for management of nitrogen cycle in ponds. The magnitude of loss of ammonia is proportional to the abundance of the nitrifiers, which is positively correlated with phytoplankton productivity, thereby enhancing fish growth. Organic fish farming is the best way for enumeration of nitrogen cycle bacteria for sustaining the quality of aquatic ecosystems. The present review focused on nitrogen biogeochemistry of aquaculture ponds with issues on use of nitrifiers as bioaugmentors for management of aquatic resources and use of essential micronutrients to a certain limit to enhance the efficacy of nitrifiers for increasing productivity. Further investigations are required to establish region-specific cost-effective methods to monitor the nitrogen cycle, thereby intensify the abundance of nitrifiers for increasing aquaculture production in a sustainable manner.
\end{abstract}

Keywords: nitrogen cycle bacteria, $\mathrm{N}$-mineralisation, $\mathrm{N}$-transformations, water quality, productivity

\section{Introduction}

Nitrogen cycle of an aquatic ecosystem is the prime nutrient cycle because nitrogen is the primary productivity limiting nutrient in such ecosystems. Nitrogen transformations in sediments include assimilation, mineralisation, nitrification and denitrification (Rysgaard et al., 1993). In the aquatic systems, bacteria play a vital role in the mineralisation of organic nitrogen by decomposition and utilisation of nitrogenous organic matters (Botan et al., 1960). Nitrogen-fixing bacteria take the responsibility of direct conversion of atmospheric $\mathrm{N}_{2}$ into biomass, whereas other organisms (plants and bacteria) use dissolved inorganic- $\mathrm{N}\left(\mathrm{NH}_{4}-\mathrm{N}, \mathrm{NO}_{2}-\mathrm{N}\right.$ and $\left.\mathrm{NO}_{3}-\mathrm{N}\right)$ or any organic forms of the element (Wallace et al., 1991).
Assimilation refers to the direct use of a substance which is coupled with the process of ammonification, a crucial step in the nitrogen cycle that causes microbial remineralisation of the organic nitrogen. The process of ammonification includes oxidative deamination in which the amine group $\left(\mathrm{NH}_{2}\right)$ is removed from the amino acid of organic matters in the form of ammonia $\left(\mathrm{NH}_{3}\right)$. Ammonia toxicity is dependent on the rate of ionisation according to the $\mathrm{pH}$ of water (Hargreaves, 1998) as unionised ammonia is more toxic to aquatic life than ionised one (Fernandes et al., 2010). Ammonia excreted by fish, other aquatic organisms, and also liberated by the decomposition of uneaten fish feed and different organic matters or metabolites, may be transformed into different forms through algal assimilation, ammonification and 
nitrification (Shilo and Rimon, 1982; van Rijn et al., 1984; Diab and Shilo, 1986). Thus, the nutrients being liberated in the culture system can be transformed into a plant or other biomass, which in turn can be easily removed and may be a valuable by-product (van Rijn, 1996). Although the unionised form of ammonia is toxic because of its ability to diffuse across the cell membrane and in comparison to ammonia and nitrite, nitrate is relatively non-toxic to fish and other aquatic species (van Rijn, 1996).

The oxidation of ammonia to nitrite is carried out by ammonia-oxidising bacteria ( $\mathrm{AOB}$ ) through the process of nitrification which is further oxidised to nitrate by the help of nitrite-oxidising bacteria (NOB) (Kumari et al., 2011). That is why the abundance of AOB and NOB demands special attention to get rid of surplus ammonia in the aquatic system. While during oxidation of nitrogen, more carbon is fixed by $A O B$ than NOB (Feliatra and Bianchi, 1993). Currently, different nitrifiers are already commercially available as bioaugmentors for wastewater treatment (Krishnani et al., 2009). The amoA gene, mostly found in the nitrifiers can be used as an essential tool to isolate different nitrifiers from the aquatic system to use them as bioaugmentors (Krishnani et al., 2009). The present review tries to focus on the use of nitrogen cycle bacteria, especially nitrifiers, with a broader range in aquaculture as well as in wastewater treatment to avoid ammonia toxicity. The study also reveals how organic farming intensifies the natural nitrification process of the ecosystem, thereby enhancing the natural productivity along with providing sustainable development. Different mineral nutrients (boron, copper, zinc, iron, manganese, molybdenum, nickel, cobalt) which influence biological nitrogen fixation, need special attention to improve soil quality (Weisany et al., 2013). Although the use of micronutrients in agricultural fields is common, the current review presents a comprehensive study on the similar use of micronutrients to enhance nitrification in aquatic system.

Phytoplankton, the most important primary producer in the aquatic ecosystem, is interconnected with nitrifying bacteria. Nitrifying bacteria produces nitrate by using ammonia which in turn is used by the phytoplankton (Kumari et al., 2011). The activity of the nitrogen cycle bacteria, in aquaculture ponds are tightly coupled with several environmental factors and management practices. The present review aims to focus on the relationship between nitrogen cycle and pond productivity with reference to the abundance of different types of nitrogen cycle bacteria and the availability of different species of nitrogen. The study also focuses on the use of organic manures which are beneficial over inorganic fertilisers since they maintain the nitrogen and other essential nutrients in proper proportions, thereby enhancing productivity. The role of nitrifiers in different management practices has also been investigated. Further study is needed to ensure an improved version for the usage of nitrifiers as bioaugmentors.

\section{Organic Decomposition, Nitrogen Mineralisation and Assimilation in Pond Ecosystem}

Nitrogen cycle plays an important role in organic matter recycling which includes nitrogen fixation, ammonification, nitrification and denitrification, carried out by a group of microorganisms (Abraham et al., 2004). Various microbial decomposers are engaged in the transformation of organic matters into the form of nutrients to make them available for uptake by plants and thereby depict recycling of nutrients known as internal cycling. Availability of nitrogen in the soil system is a rate limiting factor of absorption by plants and also has a direct impact on primary productivity. Organic $\mathrm{N}$ mineralisation is much more in the sediments of the pond than overlying water (Blackburn et al., 1988). Decomposers may be present as aerobic or anaerobic bacteria responsible for the decomposition of animal matters (Kristensen et al., 1995), whereas fungi are major decomposers of plant materials. In the sediments of the aquatic ecosystem, as oxygen levels are depleted anaerobic bacteria carry out most of the decomposition (Smith and Smith, 2006).

The transformation of organic nitrogen into mobile inorganic forms by the decomposers is known as mineralisation. At the same time, decomposers also require some nitrogen for their growth known as immobilisation. The difference between the rate of mineralisation and immobilisation is known as net mineralisation rate, which determines the net nitrogen content of the ecosystem. The microbial community holds the most crucial role in the transformation of deposited organic matters in the pond sediment, which in turn offers a source of remineralised nutrients vital for plankton growth (Burford and Longmore, 2001).

In aquaculture ecosystem, mostly in still, open water of ponds, particulate organic matter (POM) is constantly mineralised until much of the organic matter settles down as humic compounds at the bottom. In shallow waterbodies, bottom-dwelling detrivores such as crab, snail, and molluscs take much of the responsibilities together with the bacteria that work on the bottom (Covich et al., 1999). A few centimetres below the surface sediment where oxygen supply exhausted, some of the bacteria which are competent to undergo anaerobic respiration take over decomposition at a much slower rate than the bacteria of the aerobic environment in the surface sediments (Smith and Smith, 2006). Significant sources of dissolved organic matter (DOM) are freefloating macro-algae, phytoplankton and zooplankton that eat bacteria and in turn excrete nutrients as exudates and faecal pellets. Quality and the quantity of organic matter as a source of food for the decomposers directly influence the rate of 
decomposition as well as mineralisation of nitrogen (Smith and Smith, 2006). Autolysis of the phytoplankton cells or hydrolysis of other particulate organic nitrogen (PON) can produce dissolved organic nitrogen (DON) which is further mineralised by proteolytic or other heterotrophic bacteria (HB) into dissolved inorganic substances.

Nitrogen assimilation by microbial communities may serve as an $\mathrm{N}$ reservoir in an ecosystem. Therefore, nitrogen cycle bacteria play an essential role in regulating pond productivity. Microbial biomass nitrogen is the chief component of organic nitrogen in an ecosystem. Lysis of microbial cells causes the subsequent release of nitrogen (depolymerisation and ammonification) which in turn supply bioavailable nitrogen (Isobe and Ohte, 2014). Benthic mineralisation of particulate organic nitrogen also diffuses dissolved inorganic nitrogen to overlying water which fuels primary productivity (Stief, 2013).

\section{Nitrogen fixation}

Nitrogen enters into the aquatic ecosystem via two pathways of which one is atmospheric deposition such as precipitation while the other is via nitrogen fixation, which itself has two ways such as high energy fixation and biological fixation. In tropical fish ponds, during the dry season, nitrogen fixation ranges from 6 to $23 \mathrm{mg} \mathrm{N} . \mathrm{m}^{-2} \mathrm{~d}^{-1}$ while during the rainy season it varies from 21 to $57 \mathrm{mg} \mathrm{N} \cdot \mathrm{m}^{-2} \mathrm{~d}^{-1}$ and inhibition of $\mathrm{N}_{2}$ fixation is inversely correlated to the concentration of ammonia (Hargreaves, 1998). According to Vass et al. (2017), the magnitude of nitrogen fixation in freshwater fish ponds is around $5-8 \mathrm{~kg} \mathrm{~N}_{2} \mathrm{ha}^{-1} \mathrm{yr}^{-1}$. Studies by Hargreaves (1995) elucidate the role of ammonia and species composition of phytoplankton bloom as well as a significant proportion of heterocystic cyanobacteria in addition to nitrogen to aquaculture ponds. Nitrogen fixation in the presence of high energy splits $\mathrm{N}_{2}$ in two atoms of free $\mathrm{N}$ which in turn combines with hydrogen to form ammonia. Plants are capable of using mineral nitrogen, but animals can derive it only from plant materials or acquire after conversion to other nitrogenous compounds.

Nitrogen fixation is carried out by a group of diversified bacterial strains reported by different researchers (Anderson, 1955; Kuznetsov, 1970; Niewolak, 1972; Mulder, 1975; Alexander, 1978; Sprent, 1979; Jones and Simon, 1981). Bacterial nitrogen fixation is usually attributed to the aerobic azotobacters (Azotobacter agilis, Azotobacter chroococcum), facultatively anaerobic bacilli group (Bacillus polymyxa and Bacillus macerans), facultatively anaerobic klebsiellas (Klebsiella pneumoniae), anaerobic saccharolytic clostridia (Clostridium butyricum, Clostridium butylicum, Clostridium pasteurianum, Clostridium pectinovorum), and also some anaerobic sulphate reducing bacteria (Desulphovibrio and Desulphotomaculum) (Jana and
Roy, 1986). Nitrogen fixation is catalysed by dinitrogenase reductase, which is encoded by nifH gene (Krishnani and Kathiravan, 2015). According to Fernandez et al. (2020), microbes carrying anfH can also participate in nitrogen fixation and methanogenesis. The key enzymes that catalyse nitrogen fixation are nitrogenases which may be present in three different forms, where molybdenumiron nitrogenase ( $\mathrm{nifH}$ ) is the main nitrogenase gene carried by all nitrogen fixers. Vanadium nitrogenase gene ( $v n f H)$ and iron-only nitrogenase gene (anfH) may also be present as an alternative nitrogen-fixing enzyme (Fernandez et al., 2020). The iron-only nitrogenase, anfH, is capable of transforming $\mathrm{N}_{2}, \mathrm{CO}_{2}$, and $\mathrm{H}_{2}$ into $\mathrm{NH}_{3}$ and $\mathrm{CH}_{4}$ in a single enzymatic step (Zheng et al., 2018), directly linking $\mathrm{N}$ fixation to $\mathrm{CH}_{4}$ cycle. Presence of nifH, $\mathrm{VnfH}$, anfH can be used as indicators of nitrogen fixation potential.

Nitrogen-fixing bacteria (NFB), present in water and sediment samples of fish ponds are abundant with maximum growth in summer and decline in winter showing their significant adaptation to elevated temperatures of tropical ponds. The optimum $\mathrm{pH}$ and water temperature for the growth of NFB range between 6.0-7.8 and $18-34^{\circ} \mathrm{C}$, respectively (Jana and Roy, 1986). The affluence of nitrogen fixers also has an inverse and direct correlation with the amount of nitrate whereas the ammonia level of bottom water exerts a direct influence on the growth kinetics of NFB occurring in sediments (Jana and Roy, 1986). A positive correlation is present between dissolved organic matter and nitrogen-fixing bacteria (Pandey and Shreelu, 2006). Elevated temperature, low pH range may account for the greater availability of nitrogen fixers during the summer than that of winter, although it is possible only when adequate amount of dissolved oxygen (DO) is present in water.

Azotobacter spp. and Clostridium spp. are the most popular among all the nitrogen fixers with significant potential to fix nitrogen. Abundant population densities of Azotobacter sp. and Clostridium pasteurianum have been observed to be about $10^{2} \mathrm{cfu}$. $\mathrm{cm}^{-3}$ and $10^{2}$ MPN.100 $\mathrm{cm}^{-3}$ respectively in the river Drwęca (Gołaś et al., 2008) indicating the opulence of those particular bacterial strains. The cell count of nitrogen-fixing bacteria in the sediment of the waterbody was reported to be 7390 cell.g ${ }^{-1}$ while 4600 cell. $\mathrm{mL}^{-1}$ was reported from the water column (Jana and Roy, 1986) which indicates the number of nitrogen fixers is much more in the sediments of the pond than that of surface water which was also reported by Pandey and Shreelu (2006). The load of dissolved organic matter is substantially higher in the sediment than that of overlying water which implies the significant positive correlation between the nitrogenfixing bacteria and dissolved organic matter in the pond sediment. Since nitrogen is one of the prime limiting factors of the aquatic ecosystem after carbon, nitrogen stock in the system has direct control over the population dynamics of the 
ecosystem as well as ecological processes. After fixation of sufficient amount of mineral nitrogen in sediment, the rate of biological fixation significantly reduces, a dynamic equilibrium is established.

\section{Ammonification}

Ammonification is the process whereby organic $\mathrm{N}$ is mineralised to $\mathrm{NH}_{4}{ }^{+}$. It is the first step in organic $\mathrm{N}$ decomposition and is often referred to as $N$ mineralisation that causes the transformation of nitrogen contained in compounds of living organisms into inorganic ammonia $\left(\mathrm{NH}_{3}\right)$ or as ammonium ion $\left(\mathrm{NH}_{4}{ }^{+}\right.$) (Hopkinson and Giblin, 2008). A group of proteolytic bacteria may breakdown organic compounds into simpler proteins are intermediated by a group of ammonifying bacteria to liberate ammonia.

Unionised ammonia $\left(\mathrm{NH}_{3}\right)$ is more toxic than ionised ammonia $\left(\mathrm{NH}_{4}^{+}\right)$because it is able to diffuse across cell membranes (Fernandes et al., 2010). The transition between the two forms is greatly affected by $\mathrm{pH}$. At $\mathrm{pH} 7.3$ about $1 \%$ is unionised; at $\mathrm{pH} 8.3$ about $10 \%$ of ammonia is unionised, and at $\mathrm{pH} 9.3$ about $50 \%$ of ammonia is unionised (Hargreaves 1998). Elevated levels of ammonium ions $\left(\mathrm{NH}_{4}^{+}\right)$can displace potassium $\left(\mathrm{K}^{+}\right)$and depolarise neurons. This leads to the activation of the NMDA ( $\mathrm{N}$-methyl-Daspartate) type glutamate receptor, which causes an influx of calcium ions $\left(\mathrm{Ca}^{2+}\right)$ and results in cell death in the central nervous system of vertebrates (Lu et al., 2015).

Ammonia is considered as a preferred form of $N$ substrate for phytoplankton when its concentration is

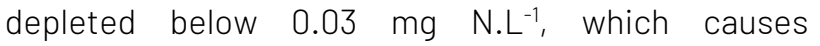
significant quantities of nitrate assimilation (Syrett, 1981; McCarthy, 1981). Nitrate assimilation, as well as its incorporation, is an energetically less-favourable process for $\mathrm{N}$ nutrition of phytoplankton as enzymatic-reduction within the phytoplankton cell takes place before the incorporation of ammonia into cellular amino acid. Both autochthonous and allochthonous types of organic matter, excretion of ammonium and amino acids by zooplankton (Brezonik, 1972), phytoplankton die-offs, excretion by fishes (Guerin-Ancy, 1976; Morii et al., 1978) and direct autolysis after cell death are chief sources of ammonia in fish ponds.

A number of micro-organisms (Escherichia coli, Aeriobacter cloacai, Pseudomonas sp., Proteus vulgaris, Bacillus subtilis and Flavobacterium sp.) are responsible for the hydrolysis of proteins into simpler compounds such as peptides, urea and amino acids which in turn are mineralised by ammonifying bacteria (AB) to liberate ammonia or ammonium sulphate (Jana and Roy, 1985b). Regarding general ecological theories, it is tempting to assume that a variety of bacterial strains with small differences between their kinetic patterns use various amino acids separately to carry out aerobic mineralisation (Sepers, 1981).

Ammonification potential highly depends on the abundance of ammonifying (AB) and heterotrophic bacteria (HB) which is also a substrate-dependent procedure. Jiao et al. (2009) have investigated the role of nitrogen cycle-related bacteria in the Buji stream in Shenzhen (China), which was reported to be severely polluted with $\mathrm{NH}_{4}-\mathrm{N}$. Furthermore, the number of $A B$ was much higher than $A O B$ and $N O B$, which indicates that the abundance of ammonifiers (AB) is substrate-dependent. However, research based on the rate of natural ammonification by using peptone as a substrate, found that ammonification varies from 7.2 to $14.6 \mathrm{mg} . \mathrm{L}^{-1}$, which is relatively higher in winter than in summer (Jana et al., 1997). The abundance of proteolytic bacteria as ammonifiers $(A B)$ is maximum during winter with a decline during summer having a positive correlation with DO (Jana and Roy, 1985b; Jana et al., 1997). The contradictory results reported by the other researchers may be due to different climatic conditions. The number of ammonifying bacteria $(A B)$ in treated sewage was reported to be the lowest in February, and the number gradually increased with increasing temperature and maximum abundance (7500 MPN. $\mathrm{mL}^{-1}$ ) was found in November (Wielgosz et al., 2010).

There are significant positive correlations between $\mathrm{NH}_{4}-\mathrm{N}, \mathrm{DO}$ and $\mathrm{AB}$, and too much acidic or alkaline $\mathrm{pH}$ inhibits the growth of $A B$, but excessive temperature fall also exerts a negative impact on the growth of $A B$. Zhao et al., (2015) reported a low abundance of $A B$ during the winter months due to temperature fall, and the number increased in spring. Jiao et al., (2009) also found a significant correlation $[r=0.9076(P<0.01)]$ between the most probable number (MPN) of $A B$ and BOD of water indicating that the ammonifying bacteria plays the most crucial role in nitrogen mineralisation. Furthermore, nitrogen-related bacteria in sediments are 100 times higher than those in overlying water as sediments are rich in organic matters. Sudthikaran et al. (2007) reported the abundance of ammonifiers in upper and lower sediments of intensive shrimp culture pond within a range of $3.3 \times 10^{2} \mathrm{MPN} \cdot \mathrm{g}^{-1}-6.7 \times 10^{5} \mathrm{MPN} \cdot \mathrm{g}^{-1}$ and $9.2 \times 10^{2}$ MPN. $g^{-1}-6.1 \times 10^{5}$ MPN. $g^{-1}$ dry weight respectively. That corroborates the observation of Jiao et al. (2009) having similar findings of greater abundance of ammonifiers in sediment. It indicates the fact of substrate dependency of ammonifying bacteria. Since higher amounts of substrates are available in the sediments than the overlying water, the bacterial abundance is proportionate to substrate availability.

\section{Nitrification}

Nitrification is two stepped oxidation of ammonium to nitrate (Kim et al., 2005; Abeliovich, 2006). The steps are: 
$\mathrm{NH}_{4}^{+}+1.5 \mathrm{O}_{2}=2 \mathrm{H}^{+}+\mathrm{NO}_{2}^{-}+\mathrm{H}_{2} \mathrm{O}$ (Step 1)

$\mathrm{NO}_{2}{ }^{-}+0.5 \mathrm{O}_{2}=\mathrm{NO}_{3}^{-}$(Step 2)

The combined equation is: $\mathrm{NH}_{4}^{+}+2 \mathrm{O}_{2}=\mathrm{NO}_{3}^{-}+2 \mathrm{H}^{+}+$ $\mathrm{H}_{2} \mathrm{O}$ (Stefanakis et al., 2014).

Nitrate typically comprises most of the increased dissolved inorganic nitrogen, and it is the most preferred non-toxic form of nitrogen incorporated in the aquatic ecosystem (Richared and John, 1996). Fish can excrete metabolic nitrogen in the form of urea (Gregory, 1977; Wright and Land, 1998). Urea can be transformed into ammonia by hydrolysis. Ammonia, in turn, is transformed into nitrite and nitrate by the process of nitrification. A nitrate concentration above $10 \mathrm{mg} \mathrm{NO}-\mathrm{N} \mathrm{L}^{-1}$ can have an adverse effect on freshwater invertebrates, fishes and amphibians by long-term exposures (Camargo et al., 2005). The main toxic action of nitrate and nitrite is their capacity to bind with haemoglobin, thereby forming methaemoglobin which makes it incapable of carrying oxygen (Hargreaves, 1998). Nitrate is relatively less toxic than ammonia and nitrite because of its low branchial permeability. Nitrite is a potential toxicant of fish which can disrupt a variety of physiological processes such as respiratory, ion regulatory, cardiovascular, endocrine and excretory system in them (Serezli et al. 2016). The extent of damage depends on $\mathrm{pH}$, temperature, cations, anions, oxygen concentration, exposure time and fish size (Kroupova et al. 2005). Freshwater fish and crustaceans are hyperosmotic and as a result, requires active uptake of ions from their surrounding environment to compensate ion loss (Kroupova et al. 2005). Whenever nitrite is present in the environment, a part of $\mathrm{Cl}^{-}$ uptake is shifted to $\mathrm{NO}_{2}{ }^{-}$uptake due to high branchial permeability of nitrite. Nitrites can accumulate in liver and retina, and long-term exposure (24-48 h) to nitrite causes rise in extracellular $\mathrm{K}^{+}$resulting in loss of $\mathrm{K}^{+}$ from RBC and skeletal muscles (Kroupova et al., 2005). Further, this leads to the depolarisation of excitable tissues resulting in severe problems like heart failure and nerve malfunction.

Nitrification is a two-step microbiological process guided by two groups of nitrifiers. In the first step, ammonia is oxidised to nitrite by ammonia-oxidising bacteria (AOB) (Fig. 1) which is subsequently oxidised to nitrate (Fig. 1) by nitrite-oxidising bacteria (NOB) (Kim et al., 2005; Abeliovich, 2006; Kumari et al., 2011; Daims et al., 2016). Research on Buji stream in Shenzhen (China) pointed towards the fact that very low proportion of nitrifiers ( $\mathrm{AOB}$ and $\mathrm{NOB}$ ) is the major cause of nitrogen toxicity (Jiao et al., 2009). Enrichment of the nitrifiers enhances the rate of nitrification, which is a vital step of the nitrogen cycle to balance the nitrogen budget of the particular ecosystem.

Nitrifying bacteria capable of oxidising ammonia- $\mathrm{N}$ to nitrite- $\mathrm{N}$ in the first step is largely confined to the genus Nitrosomonas, Nitrosococcus, Nitrosospira and
Nitrosolobus and nitrite to nitrate in the next step is confined to genus Nitrobacter (Jana and Roy, 1985a). Santos et al. (2019) validate the same and have mentioned about Nitrosovibrio as $\mathrm{AOB}$ and Nitrococcus and Nitrospina as NOB. The presence of some chemoautotrophic ammonia oxidisers such as Nitrosomonas europaea as well as nitrite oxidisers such as Nitrobacter winogradskyi in large numbers can cause autotrophic nitrification in inland waters (Jana and Roy, 1985a). Nitrosomonas europaea is considered as the best autotrophic ammonia oxidiser by Wrage et al., 2001. Autotrophic AOB are Gram-negative and are traditionally placed within the Nitrobacteriaceae (Prosser, 2005) which are aerobes and many of them are obligate autotrophs (Wrage et al., 2001). Nitrosococcus oceanus has been placed in $\gamma$ probacteria and Nitrosospira, Nitrosococcus mobilis, Nitrosomonas europaea, Nitrosomonas communis, Nitrosomonas marina, Nitosomonas cryotolerans, Nitrosomonas oligotropha and Nitrosomonas sp. have been placed in $\beta$-proteobacteria. While in case of NOB most of the species of Nitrobacter are placed in $\alpha$ proteobacteria (Prosser, 2005). Recently two phototrophic NOB strains were isolated from sewage, namely Rhodopseudomonas sp. and Thiocapsa sp. which are capable of using $\mathrm{HS}^{-}, \mathrm{H}_{2}, \mathrm{Fe}^{2+}$ and many other organic compounds as reductants (Isobe and Ohte, 2014).

In autotrophic ammonia oxidisers, two enzymes play the pivotal role for energy conservation during the oxidation process; namely ammonia monooxygenase (AMO) which catalyses the oxygenation of ammonia to hydroxylamine and hydroxylamine oxidoreductase ( $\mathrm{HAO}$ ) which catalyses the oxidation of hydroxylamine to nitrite (Bothe et al., 2000). The AOB, Nitrosomonas marine is an obligatory, aerobic, Gram-negative halophile proteobacterium (Burrell et al., 2001) whereas Nitrobacter is facultative chemoautotrophic and mainly found in the terrestrial and aquatic environment. Nitrococcus mobilis is an obligate halophile which oxidises nitrite to nitrate and is found in lower numbers than other nitrifying bacteria (Santos et al., 2019). Nitrospira moscoviensis and Nitrospira marine are reported to be obligated chemoautotrophic (Santos et al., 2019). Some species of Pseudomonas are heterotrophic bacteria which are responsible for the reduction of nitrate and phosphate. Nitrospira spp. and Nitrosomonas oligotropha are the dominant ammonia-oxidisers in environments having low $\mathrm{N}-\mathrm{NH}_{4}{ }^{+}$concentrations, but Nitrosomonas europaea and Nitrosococcus mobilis are mostly predominate in $\mathrm{N}-\mathrm{NH}_{4}{ }^{+}$rich environment (Limpiyakorn et al., 2005). Nitrification is also a pH dependent procedure which varies from species to species. Nitrosomonas europaea is capable of hydrolysing urea at a $\mathrm{pH}$ value of 8.0 whereas Nitrosospira can utilise urea as sole nitrogen source at pH 5.5 (Allison and Prosser, 1991). Most of the AOB belongs to $\beta$ subdivision of class proteobacteria except Nitrosococcus, which belongs to $\gamma$ subdivision (Burrell et al., 2001). Nitrobacter winogradsky is 
autotrophic nitrite-oxidising bacteria which belong to a subdivision of the Proteobacteria and many other chemolithoautotrophic nitrite-oxidising Proteobacteria may belong to $\alpha, \delta$ and $\gamma$ subdivisions (Hovanec and DeLong, 1996). The amoA gene codes for ammonia monooxygenase that catalyses the oxidation of ammonia into hydroxylamine (Krishnani et al., 2009). It is very specific for nitrifying bacteria, thus creating interest to study genetic differences among different species of AOB. PCR amplification of this amoA is now being used as an excellent tool to analyse different ammonia-oxidisers for efficient ammonia removal from different ammonia-polluted aquaculture systems. On the other hand, nxrA and $n \times r B$ are reported as a useful phylogenetic marker to identify uncultured NOB (Daims et al., 2016).

Nitrification is a complex process affected by a variety of interrelated factors such as DO concentration, temperature, substrate concentration, $\mathrm{pH}$, nutrients availability, number of nitrifying bacteria and their availability of surfaces (Kumari et al., 2011). In comparison to NOB, AOB grows extremely slowly ( $\mu_{\max }$ $=0.5 \mathrm{~d}^{-1}$ ) as its only source of energy is ammonia oxidation and source of carbon is $\mathrm{CO}_{2}$ fixation (Kim et al., 2005). Ammonia monooxygenase (AMO) is a membrane-integrated enzyme of $A O B$ which catalyses the oxidation of ammonia to hydroxylamine known to be sensitive to environmental factors (Kim et al., 2005). Thus, the activity of the ammoniaoxidising bacteria shows seasonal variation.

Oxygen penetration is the key regulating factor for both the ammonia and nitrite oxidation process as nitrification takes place above the $\mathrm{DO}$ concentration of $2 \mathrm{mg} . \mathrm{L}^{-1}$ (Rysgaard et al., 1994). As a result, during the summer, nitrification in the sediments of aquaculture pond is most likely to be limited by the depth of oxygen penetration which is typically 1 to 5 $\mathrm{mm}$ (Hargreaves, 1998). Dissolved oxygen acts as a controlling factor in nitrification, introduces a Michaelis-Menten function (with half-saturation constant $\mathrm{kO}_{2}$ ) where the decreasing rate of ammonium oxidation occurs with declining oxygen concentrations (Yool, 2011). During summer, the rate of nitrification decreases along with decreased oxygen penetration which indicates a positive correlation of DO with the abundance of $\mathrm{AOB}$ and NOB. Ammonia oxidation is inhibited by light, and the competition of $\mathrm{AOB}$ with phytoplankton and heterotrophic bacteria for using ammonium also exerts a negative impact on ammonia oxidation, both of which are minimised during winter. Therefore the abundance of ammonia-oxidiser is highest during winter. But during summer, higher abundance of $\mathrm{AOB}$ and NOB (Christman et al., 2011) may be due to temperature extremities in the polar regions.

Although nitrite-oxidisers are considered to be obligate aerobes, many can utilise nitrate as an electron acceptor in the absence of oxygen. Nitriteoxidisers can grow in totally anaerobic environments such as at the bottom of deep anaerobic wastewater reservoirs, deep in the mud, even in the absence of both nitrate or oxygen where significant concentrations of sulphides are present (Abeliovich, 2006). Nitrifying bacteria can stay alive for several months in the anaerobic sediments of aquatic systems and can resume their activity rapidly once oxygen is supplied (Cavari, 1977). Investigation on the abundance of $\mathrm{AOB}$ in aquaculture ponds by quantitative PCR of the amoA gene (encoding alpha subunit of $A M O$ ) showed maximum abundance of $A O B$ during winter and autumn, and the number decreases during summer (Lu et al., 2015). The abundance of the nitrifiers (viz. AOB, NOB) has a positive correlation with $\mathrm{DO}$ and different species of nitrogen such as ammonium- $\mathrm{N}$, nitrite- $\mathrm{N}$, nitrate- $\mathrm{N}$ and inversely correlated with temperature. The abundance of nitrifiers are within the range of $720-1848$ cells. $\mathrm{mL}^{-1}$ of AOB in water and it lies within the range of 780-2325 cells. $\mathrm{g}^{-1}$ in sediments with seasonal peaks during winter in both water and sediments (Jana and Roy, 1985a). Remarkable temporal variation of abundance of ammonia-oxidisers in different ponds of Lucknow (India), in surface and bottom water, showed minimum values in summer and maximum in the rainy season (Kumari et al., 2011). Christman et al. (2011) mentioned the occurrence of peak nitrifiers in summer.

Climatic differences among different places are the probable reasons for contradiction because in the cooler region, the winter temperature may fall beyond the optimum temperature range required for the growth of nitrifiers and nutrient limitation is also a major factor for the decrease of the abundance of nitrifiers. However, in the temperate region, winter temperature offers suitable conditions for the growth of nitrifiers which may be the probable cause of winter peak. The spatial variation of the count of ammonia-oxidisers is substantial with higher values in bottom water $\left(1297 \pm 3.6\right.$ to $1673.23 \pm 0.36 \mathrm{~mL}^{-1}, 1074 \pm$ 1.07 to $1372.17 \pm 4.6 \mathrm{~mL}^{-1}$ and $435.05 \pm 15.7$ to $547.54 \pm$ $\left.2.12 \mathrm{~mL}^{-1}\right)$ compared to surface water $(720.5 \pm 8.1$ to $955.3 \pm 10.8 \mathrm{~mL}^{-1} 515 \pm 10.1$ to $678 \pm 11.8 \mathrm{~mL}^{-1}$ and $218.7 \pm$ 7.3 to $368.4 \pm 9.32 \mathrm{~mL}^{-1}$ ) during rainy, winter and summer seasons respectively and similar distribution pattern is also followed by nitrite-oxidising bacteria (Kumari et al., 2011). The reason may be a higher nutrient load in the bottom water than that of the surface water. Among the nitrifiers, ammoniaoxidisers occupy a greater proportion than that of nitrite-oxidisers. Ammonia-oxidisers (AOB) are within a range of 0-240 MPN.g ${ }^{-1}$ dry weight in the upper and lower layers of sediments, whereas, nitrite-oxidisers (NOB) are within a range of 0-2.9 MPN.g-1 dry weight, detected only in the upper sediment layer of intensive shrimp culture pond (Sudthikaran et al., 2007). Nitriteoxidisers are more sensitive to environmental factors than that of ammonia-oxidisers (Dvir et al., 1999). It implies the greater abundance of the ammoniaoxidisers than nitrite-oxidisers. 
The optimum ranges of temperature, $\mathrm{pH}$ and $\mathrm{DO}$ for nitrification are 20-30 ${ }^{\circ} \mathrm{C}, 7-8$ and 5-10 mg. $\mathrm{L}^{-1}$, respectively (Diab et al., 1993). Nitrification tends to be inhibited below $5{ }^{\circ} \mathrm{C}$ with a lower $\mathrm{pH}$, and complete inhibition takes place at pH 5.5 (Eddy and Williams, 1987) while the activity of Nitrosomonas decreases with increasing $\mathrm{pH}$ above the optimum range (Feliatra, 2001). Rate of ammonia oxidation drops during the night due to decrease in $\mathrm{pH}$ values and temperature, and as a result, in the early morning, the dominant product of nitrification is nitrate (Dvir et al., 1999). Nitrification potential (NP) is directly proportional to the number of nitrifying bacteria. Once ammonia concentration is depleted, it indicates a subsequent increase in the level of nitrite and thereby an increase in nitrate concentration (Cavari, 1977). The concentration of ammonia is a factor which influences the activity of nitrifiers (viz. AOB, NOB) (Jana et al., 1997; Stefanakis et al., 2014) and ammonia concentration below $5 \mu \mathrm{g}$ atom. $\mathrm{L}^{-1}$ ceases nitrification in the ocean (Wada and Hattori, 1971).

At the surface of the water, the nitrification activity is minimal because of the competition between ammonia-oxidisers and plankton to consume ammonia. While researchers using allylthiourea as $A O B$ inhibitor and chlorate as NOB inhibitor have found that in the absence of nitrifiers (viz. AOB, NOB) the ammonia concentration becomes so toxic that it cannot support shrimp survival (Feliatra, 2001). Nitrification benefits on production system are observed when systems with nitrifiers are compared with systems without nitrifiers (Mahanta et al., 2014). When using nitrifying bacterial inoculant in bioremediation, the concentration of ammonia and nitrite are under control with aeration while the rate of nitrification is slower without aeration (Barik et al., 2018). This indicates the beneficial role of the nitrifiers in maintaining water quality of ponds.

\section{De-nitrification}

Denitrification plays a significant role in lowering total nitrogen concentration or continuous emission of surplus nitrogen from aquatic systems which are necessary to maintain the conducive water quality of the systems. Denitrification is the next step in the nitrogen cycle chain, where ammonium- $\mathrm{N}$ includes the reduction of the transformed nitrite and nitrate to nitric oxide, nitrous oxide, and $\mathrm{N}_{2}$ gas by denitrifying bacteria (DNB) (Wrage et al., 2001). Denitrification causes the transformation of oxidised inorganic nitrogenous compound to elemental nitrogen (van Rijn. et al., 2006). Ammonification and nitrification contribute to changes in the forms of nitrogenous compounds, while denitrification offers the elimination of $\mathrm{NO}_{3}-\mathrm{N}$ through their reduction to gaseous nitrogen (Fig. 1) and permits a decrease in the content of total nitrogen (Wielgosz et al., 2010).

Denitrification is higher in a nutrient rich system where denitrifiers (DNB) play a crucial role in maintaining the cycling of nitrogen, thereby maintaining the integrity of the ecosystem by preventing eutrophication (Sousa et al., 2013). Denitrification is a reductive process to get rid of excess nitrate and nitrite which can be produced as a by-product of excess feed and different types of decayed organic wastes from animals in aquaculture ponds and thereby produce toxic effects to animals at higher concentrations. So denitrification is the conversion of nitrate $\left(\mathrm{NO}_{3}\right)$ into atmospheric nitrogen $\left(\mathrm{N}_{2}\right)$ through nitrite $\left(\mathrm{NO}_{2}\right)$, nitric oxide $(\mathrm{NO})$, and nitrous oxide $\left(\mathrm{N}_{2} \mathrm{O}\right)$ (Kathiravan and Krishnani, 2014) using the intermediate products as alternative $e^{-}$acceptors for energy production in anaerobic condition (Vass et al., 2017).

Bacteria such as Pseudomonas, Micrococcus, Bacillus, Thiobacillus, Propionibacterium and many others are able to convert nitrate (Wrage et al., 2001). Facultative heterotrophic bacteria such as Achromobacter, Aerobacter and Bacillus also take part in denitrification (Wielgosz et al., 2010). The entire denitrification process requires the involvement of four enzymes such as nitrate reductase, nitrite reductase, nitric oxide reductase and nitrous oxide reductase (Chen et al., 2011). Most of the denitrifying bacteria possess either nirS gene that encodes cytochrome cd1 (cd1 NIR) or nirk gene that encodes Cu-containing enzyme for nitrite reduction (Cu NIR) (Bothe et al., 2000). The genes narG and napA code for nitrate reductase, nirk/ nirS codes for nitrite reductase, nor codes for nitric oxide reductase and nosZ codes for nitrous oxide reductase (Krishnani and Kathiravan, 2015). The PCR analysis of these genes can be used for isolating DNB from the environment.

Most of the denitrifying bacteria are facultative anaerobes and canuse nitrate as $e^{-}$acceptor in place of oxygen to cope up with low $\mathrm{O}_{2}$ or anaerobic conditions (Wrage et al., 2001). The $\mathrm{N}_{2} \mathrm{O}$, a regular intermediate of denitrification is released at maximum level when $\mathrm{pH}$ is low because $\mathrm{N}_{2} \mathrm{O}$ reductase is inhibited at this low $\mathrm{pH}$ although $\mathrm{NO}_{3}^{-}$is preferred over $\mathrm{N}_{2} \mathrm{O}$ as $e^{-}$acceptor (Wrage et al., 2001). At high $\mathrm{O}_{2}$ concentration, aerobic respiration of the DNB inhibit $\mathrm{NO}_{3}^{-}$reduction (Wrage et al., 2001). Apart from that $\mathrm{C}_{2} \mathrm{H}_{2}$ may be considered as a specific inhibitor of denitrification (Yoshinari et al., 1977).

Factors which play a vital role in controlling the rate of denitrification mainly include nitrate concentration, availability of organic carbon, DO, temperature and $\mathrm{pH}$ (Rathsack et al., 2014). Denitrification has three limiting factors, such as nitrate concentration, organic carbon and anoxic conditions (Stefanakis et al., 2014). Sediments are oxygen deficient and rich in organic matter which makes it preferable for denitrification than that of the overlying water. Researchers detected DNB within a range of 0-670 MPN. $g^{-1}$ dry weight in the upper layer, and 0-1271 MPN. $\mathrm{g}^{-1}$ dry weight in the lower layer in intensive shrimp culture pond (Sudthikaran et al., 2007). The probable 
cause of this result may be related to the decreasing concentration of DO from the upper layer of water to the lower layer. Denitrification decreases with an increase in $D 0$ concentration in water from 0-2 mg. $\mathrm{L}^{-1}$ while a further increase of DO does not exert any decreasing effect (van Kessel, 1977). Wielgosz et al. (2010) mentioned that the process of denitrification increases with sufficient supply of $\mathrm{NO}_{3}-\mathrm{N}$ and readily

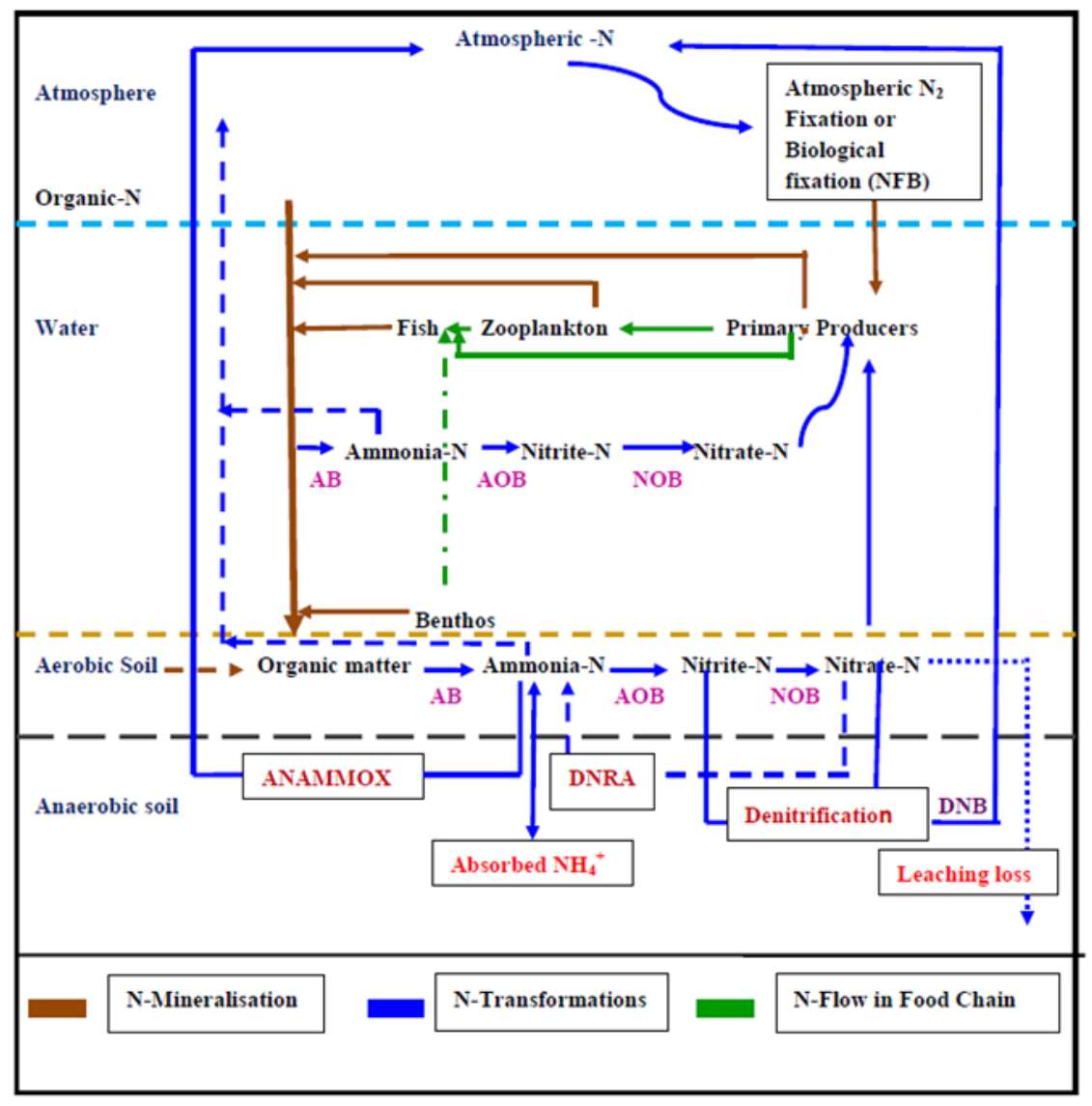

Fig. 1. Schematic representation of nitrogen transformations in aquatic system (Adapted from: Herbert, 1999; Wongkiew et al., 2017).

available carbon substrates if oxygen concentration does not exceed $0.5 \mathrm{mg} \mathrm{O}_{2} \mathrm{dm}^{-3}$.

Further increase in oxygen concentration slows down denitrification since the bacteria start to utilise 00 as a source of oxygen and not the oxygen contained in $\mathrm{NO}_{3}-\mathrm{N}$. Maximum abundance of DNB during spring and lowest number during winter (Zhao et al., 2015) emphasises the fact that DNB may have a negative correlation with DO. Researchers observed the highest number of DNB during November in treated sewage (Wielgosz et al., 2010). Contradictory results have also been reported, for example, in fish farming ponds, the maximum abundance of DNB was observed during summer $\left(10^{4}\right.$ cells. $\left.\mathrm{g}^{-1}\right)$ and minimum during winter $\left(10^{3}\right.$ cells.g $\left.{ }^{-1}\right)$ (Jana and Patel, 1985). Thus, the seasonal peak of the DNB changes according to the climate.

Denitrification is also temperature-dependent and shows a positive correlation with temperature. Below $5{ }^{\circ} \mathrm{C}$ the entire procedure of nitrification ceases due to inhibition of bacterial growth, and low temperatures also have a negative impact on denitrification (Wielgosz et al., 2010). Rate of denitrification highly depends on the rate of transport of nitrate from overlying water to sediment and also on the nitrate concentration of the overlying water. At lower nitrate concentration, it follows first-order kinetics but gradually as the nitrate concentration increases, it becomes independent of the nitrate concentration and follows zero-order kinetics (van Kessel, 1977). Low DO and organic compounds are beneficial for the process of denitrification and the entire procedure is largely restricted by the low concentration of nitrite and nitrate (Jiao et al., 2009). Most probable number of the denitrifying bacteria has a positive correlation with BOD and the concentration of nitrogenous compound with correlation coefficients of 0.6642 and $0.6636(P<0.05)$ respectively (Jiao et al., 2009).

Denitrification causes continuous emission of valuable nitrogen from the system resulting in nutrient loss. Procyanidins from Fallopia spp. have the ability to inhibit bacterial denitrification termed as biological denitrification inhibition (BDI). Pseudomonas brassicacearum responds by expressing membrane bound $\mathrm{NO}_{3}$-reductase and procyanidins inhibit membrane-bound $\mathrm{NO}_{3}$-reductase 
encoded by narG gene induce conformational changes of the enzyme through membrane disturbance (Bardon et al., 2016). Further study should be carried on for the inhibition of $\mathrm{NO}_{2}$-reductase encoded by the nirs gene to prevent nitrogen loss through denitrification, although denitrification is an important nitrogen budget limiting process and is beneficial up to a certain level.

\section{$\mathrm{N}$-loss by anammox and ammonia volatilisation}

Supply of available substrates may regulate nitrogen loss in the ecosystem. In the sub-oxic zone and oxygen-minimum zones, $\mathrm{N}$-loss mainly occurs through anammox (anaerobic ammonia oxidation/ ammonia-dependent denitrification) reaction and this anammox (Fig. 1) may also regulate ammonia production known as dissimilatory nitrate reduction to ammonium (DNRA) (Isobe and Ohte, 2014). Anammox is carried out by bacteria belonging to the phylum Planctomycetes which oxidise ammonia to produce gaseous nitrogen by using nitrite as the electron acceptor (Yadav, 2014). Anammox was first discovered in wastewater treatment plant although it is considered as a major factor for most of the $\mathrm{N}$-loss in ocean whereas in other systems denitrification is more responsible for $\mathrm{N}$-loss (Fig. 1). Denitrification is related to nitrate ammonification and may be related to the anaerobic ammonia oxidation termed as anammox reaction. Nitrate ammonification is typical for the Enterobacteriaceae, such as Wolinella succinogenes and Sulforospirillum deleyianum (Bothe et al., 2000). The first step causes the reduction of nitrate to nitrite which is catalysed by a nitrate reductase which has similarities with the enzyme in denitrifying bacteria (Bothe et al., 2000). In the second step, a cytochrome c-dependent nitrite reductase catalyses the reduction of nitrite to ammonia. Escherichia coli contains at least two different membrane-bound nitrate reductases which are periplasmic nitrate reductases (Bothe et al., 2000). The genes, narG and napA encoding two distinct nitrate reductases (NAR and NAP), mediate the reduction of nitrate to nitrite in both denitrifying bacteria and DNRA. The subsequent reactions are carried out by nirs and nirk gene in denitrifying bacteria but in case of DNRA, nitrite is reduced to ammonium by enzymes encoded by nrfA gene (Dong et al., 2009).

Ammonia in aquatic ecosystems is available in ionised $\left(\mathrm{NH}_{4}{ }^{+}\right)$or in unionised gaseous $\left(\mathrm{NH}_{3}\right)$ form depending on the $\mathrm{pH}$ and temperature of the water (Zhou and Boyd, 2015). Elevated $\mathrm{pH}$ and high temperature generally favours the unionised gaseous form of ammonia (Camargo Valero and Mara, 2010). Depending on the $\mathrm{pH}$, temperature and partial pressure of ammonia in atmosphere above the water surface, volatilisation of ammonia takes place when the equilibrium between ammonia $\left(\mathrm{NH}_{3}\right)$ and ammonium
$\left(\mathrm{NH}_{4}^{+}\right)$is shifted towards the free form (Camargo Valero and Mara, 2010).

\section{Different Forms of Nitrogen and Pond Productivity}

Nitrifying bacteria have a unique correlation with phytoplankton with respect to their usage of ammonia and nitrite. Nitrate produced by nitrifiers ( $\mathrm{AOB}$ and $\mathrm{NOB}$ ) is used by phytoplankton, considered as important primary producers in the aquatic ecosystem (Kumari et al., 2011). Nitrate uptake by phytoplankton may enhance the productivity of zooplankton and the productivity of detritus (Yool, 2011), thereby offering more food for the fishes. Nitrogen can exist in a variety of dissolved and particulate forms in the aquatic system that can be used for phytoplankton production directly or indirectly and incorporation of nitrate may enhance the carbon uptake by phytoplankton depending upon the salinity of water (Montgomery et al., 1991). Nitrogen uptake by phytoplankton is an influential mechanism for the conversion of toxic inorganic $\mathrm{N}$ to relatively non-toxic organic $\mathrm{N}$. Nitrogen demand of the phytoplankton depends on the rate of supply of inorganic nitrogen to the euphotic zone. The principal sources of nitrogen in the aquatic system which promote phytoplankton growth are molecular nitrogen by nitrogen fixation, surface runoff of ammonium and nitrate, turbulent diffusion of ammonium and nitrate from aphotic bottom water and sediments, and internally regenerated ammonia or urea discharged through excretion and mineralisation processes (Axler et al., 1981). The preferred $\mathrm{N}$ substrate for phytoplankton is ammonia because nitrate incorporation and assimilation is an energetically less-favourable pathway as enzymaticreduction of ammonium is necessary within the phytoplankton cell for inclusion into cellular amino acids (Hargreaves, 1998). Measurement of nitrate uptake with radiotracer ${ }^{13} \mathrm{~N}$ and ammonia uptake with stable isotope ${ }^{15} \mathrm{~N}$ analysed that ammonia assimilation may have a positive relation with plankton productivity (Axler et al., 1981). Ammonia excreted by zooplankton can successfully be used by phytoplankton, thereby increasing their productivity. Nitrogen uptake by phytoplankton ranges from 151 to $453 \mathrm{mg} \mathrm{N} . \mathrm{m}^{-2} \mathrm{~d}^{-1}$ in temperate ponds, and from 750 to $1,500 \mathrm{mg} \mathrm{N} \cdot \mathrm{m}^{-2} \mathrm{~d}^{-1}$ in tropical ponds and a net fish yield of 30-40 kg.ha-1 $\mathrm{d}^{-1}\left(3-4 \mathrm{~g} \cdot \mathrm{m}^{-2} \mathrm{~d}^{-1}\right)$ is possible at a loading of $700-800 \mathrm{mg} \mathrm{N} \cdot \mathrm{m}^{-2} \mathrm{~d}^{-1}$ to the aquaculture ponds in the form of organic or inorganic fertiliser (Hargreaves, 1995). Nitrogen budget of the aquaculture pond and the subsequent transformation of the nitrogenous compound to more favourable species of nitrogen is the prime regulator of pond productivity as well as fish growth. Nitrogen assimilation in the aquaculture ponds changes according to climatic differences among places. 


\section{Nitrogen Mineralisation and Organic Fish Farming}

Every ecosystem presents special characteristics regarding nitrogen compounds. Fish farming ponds which are fertilised by organic manures are one of such ecosystems whose eutrophy is under control, to increase fish productivity (Montuelle et al., 1992). The biological productivity of an aquatic ecosystem is generally judged through the qualitative and quantitative analysis of plankton, which serves as the natural food of fish. The input of animal wastes in the aquaculture ponds increase biological productivity of ponds which in turn increase fish production (Oribhabor and Ansa, 2006). Application of inorganic fertilisers in aquaculture ponds results in deficiency of quality and quantity of essential nutrients in the form of carbon, nitrogen and phosphorous (Jana et al., 2001a). While chemical fertilisers are often used for rapid solubilisation of nutrients though they are expensive and may cause some unfavourable effects on soil structure, composition, micro-flora, macroflora and many other characteristics of the pond ecosystems (Jana et al., 2001a). However, organic manures contain almost all the essential nutrients that enrich the organic matter content of pond soil and the input of organic manures stimulate the degradation rate of sedimented particulate organic matter (Jana et al., 2001b).

Livestock farming, together with aquaculture provides a new dimension of sustainable development with a satisfactory amount of annual fish yield. With the application of chicken manure, $70 \%$ of input $N$ accumulates in the tropical fish pond (Hargreaves, 1998). Researchers detected the effect of different doses of mixed fertiliser composed of poultry droppings, cattle manure, single super phosphate and urea on the response of some biogeochemical cycling bacteria and observed that overall counts of HB (15$\left.270 \times 10^{3} \mathrm{~mL}^{-1}\right)$, cellulose decomposing bacteria (CDB) $\left(15-237 \times 10^{2} \mathrm{~mL}^{-1}\right), \operatorname{DNB}\left(5-221 \times 10^{2} \mathrm{~mL}^{-1}\right)$ and phosphate solubilising bacteria (PSB) $\left(3-159 \times 10 \mathrm{~mL}^{-1}\right)$ in water and $\mathrm{HB}\left(32-249 \times 10^{4} \mathrm{~mL}^{-1}\right), \mathrm{CDB}\left(31-236 \times 10^{3}\right.$ $\left.\mathrm{mL}^{-1}\right)$, DNB (26-186 $\left.\times 10^{4} \mathrm{~mL}^{-1}\right)$ and PSB (13-162 × $10^{2}$ $\left.\mathrm{mL}^{-1}\right)$ in sediment increased with increasing dose of the mixed fertilisers (Bhakta et al., 2006). Maximum bacterial growth is observed at a fertiliser dose of $48000 \mathrm{~kg} \cdot \mathrm{ha}^{-1} \mathrm{yr}^{-1}$, while further increase slows down bacterial activity (Bhakta et al., 2006).

Increase in the abundance of biogeochemical cycling bacteria causes a parallel increase in the productivity of plankton which is positively correlated with fish growth and survival. Manure application incorporates the essential nutrients in the system and also triggers the natural primary productivity, but nutrient overloading deteriorates water quality which may lead to eutrophication. That is why manure application up to a specific dose is supportive to fish growth and over stimulation shows an inhibitory effect on productivity. In a similar type of research with poultry droppings, cattle manure, single super phosphate and urea, the maximum amount of nitrogen (ammonia, nitrite, nitrate) is found in the fish pond treated with poultry droppings followed by a combined fertiliser of poultry droppings and cow dung which conclude the same (Jana et al., 2001b). Organic manuring offers fish farming production intensification by balancing the proportion of carbon to other important nutrient parameters such as nitrogen and phosphorus (Mlejnkova and Sovova, 2012). Addition of organic carbon sources to the aquaculture ponds stimulates the growth of heterotrophic bacteria and induces nitrogen consumption to provide microbial protein to the aquaculture ecosystem. This results in the accumulation of different microorganisms, protozoa and algae, which generate microbial protein as feed (Qin et al., 2016). Therefore, in case of organic farming, input of the nutrients in the aquaculture pond is high that will lead to a subsequent increase in the microbial population which in turn will increase the productivity of phytoplankton, zooplankton and various other fish feed in the aquatic ecosystem.

Previous reports indicate that fish growth increases with the increase in fertiliser doses, having a positive correlation with bacterial loading. However, after a certain dose though the bacterial load increases, it does not influence the primary productivity and fish growth. So, from the above observation, it can be concluded that even in the case of organic farming application of the fertiliser should be dose-specific; otherwise, it can cause environmental pollution. Banerjea (1967) has studied soil and water properties of some freshwater fish ponds of India and has suggested that soluble inorganic $\mathrm{N}$ below $0.1 \mathrm{mg} . \mathrm{L}^{-1}$ can deduct productivity of fish ponds while values above $0.2 \mathrm{mg} . \mathrm{L}^{-1}$ provide favourable conditions. Application of nitrogen in the form of fertiliser should not exceed pond assimilatory capacity; otherwise, it may have an adverse effect on water quality by the accumulation of toxic nitrogenous compounds. Researchers have also stated that production of the fish farming ponds can be limited by a surplus of nitrogen and high stocking density (Jana and Roy, 1985a). Elevated concentration of ammonia in pond water causes gill damage, reduction in oxygencarrying capacity of haemoglobin, lack or depletion of adenosine triphosphate (ATP) in the brain of fish (Zhou and Boyd, 2015) and in addition to that contributes to the eutrophication of water bodies.

Addition of acid to lower $\mathrm{pH}$, application of an algaecide to lessen phytoplankton photosynthesis and to reduce $\mathrm{pH}$, or exchanging of water in ponds to flush out ammonia can be used as emergency percussions where the TAN concentration is too high (Zhou and Boyd, 2015). The concentration of ammonia-N above $1.5 \mathrm{mg} \mathrm{N} \mathrm{L}^{-1}$ is toxic to commercially cultured fish and in case of stagnant water pond total ammonium nitrogen (TAN) accumulates due to insufficient nitrification (Crab et al., 2007). To get rid of those problems associated 
with ammonia toxicity periodic aeration of the pond sediment by drainage, use of nitrifying filters in aquaculture applications and addition of carbohydrates to the pond to enhance bacterial growth and nitrogen uptake are beneficial for flushing out excess ammonia. Less than $10 \%$ of ammonia is in toxic form when $\mathrm{pH}$ is less than 8 , and that is the reason for adding acid to the ammonia polluted water. In addition, increase water exchange, a source of organic carbon, acid application, ion exchange materials and bacterial amendments can be used to dilute ammonia concentration and to maintain the $\mathrm{pH}$ (Hargreaves and Tucker, 2004). Carbon and nitrogen ratio in the system also plays a vital role in the conversion of ammonium (Crab et al., 2007). So, the addition of a source of organic carbon will reduce ammonia concentration. Addition of phosphorus increases algal growth, thereby causing an increase in ammonia uptake by algae (Hargreaves and Tucker, 2004). Ntrifiers take a vital role for immobilisation of ammonia strongly influencing nitrogen retention in the system. Various nitrifiers ( $\mathrm{AOB}$ and $\mathrm{NOB}$ ) are capable of forming biofilms for the treatment of ammonia polluted water (Hoang et al., 2016). Biofloc technology which is based on promoting aerobic microorganism growth in culture containers that use different molecules to grow and multiply can be used to recycle nitrogen thereby maintaining the water quality (Jiménez-Ojeda et al., 2018). Probiotics, which are biofriendly microorganisms are used in a sustainable form of aquaculture (Hasan et al., 2012). In addition, natural ion exchanger such as zeolite can be used for removing ammonia from water in aquaculture system.

\section{Usage of Nitrifying Bacteria in Aquaculture and its Future Prospects}

Polluted water gives rise to different fish diseases and to overcome the problem, antibiotics are used indiscriminately. Antimicrobial use in aquaculture may develop resistance gene in bacteria which may be disseminated through horizontal gene transfer (Fečkaninová et al., 2017) to other animals and fish leading to serious health hazards to human consumers. Conversely, $\mathrm{NO}_{2}$ volatilisation may also present a serious environmental issue. Different oxides of nitrogen are dominant greenhouse gases and also cause photochemical smog. Nitrous oxide $\left(\mathrm{N}_{2} \mathrm{O}\right)$ is an important greenhouse gas (GHG) which has 300 times higher global warming potential than that of carbon dioxide $\left(\mathrm{CO}_{2}\right)$ (Ahn et al., 2010). Subtropical coastal aquaculture ponds are critically responsible for $\mathrm{N}_{2} \mathrm{O}$ emission causing an adverse effect on global warming. Currently, $\mathrm{N}_{2} \mathrm{O}$ discharge from the aquaculture ponds is a serious problem to the environment and may have an adverse effect in the near future.

At low oxygen concentration and high ammonia concentration, nitrification may also enhance $\mathrm{N}_{2} \mathrm{O}$ production (Bianchi et al., 1994). Disruptions of the nitrogen biogeochemical cycle may also cause acidification of aquatic system and may lead to biodiversity loss. Researchers should focus on devising satisfactory methods to minimise $\mathrm{N}_{2} \mathrm{O}$ emission. Aquaponic and biofloc technology may be considered as useful branches of biotechnology to manage these problems. Different nitrifying bacteria are grabbing special attention because of their use in aquaculture to maintain the nitrogen budget of the aquatic ecosystem and also for sludge and wastewater treatment. Nitrifying bacteria can be used for purification of brackish water ponds (Feliatra, 2003). Nitrosomonas nitrosa and some other species of Nitrosomonas are already available in the GenBank to be used for ammonia removal from brackish water aquaculture systems (Krishnani et al., 2009). Polymerase chain reaction can be used to amplify the 16S rRNA genes of specific nitrifier groups to improve the sensitivity (Siripong et al., 2006). Water quality may deteriorate rapidly due to total ammonium nitrogen accumulation which may lead to decreased productivity.

The airlift reactor consisting of immobilised culture of nitrifying bacteria on polyvinyl alcohol beads is efficient for ammonia removal in both freshwater and saline water (Shan and Obbard, 2003). Nitrification activities of ammonia oxidising bacteria (AOB) and nitrite oxidising bacteria (NOB) cause nutrient removal in wastewater treatment plant. $\mathrm{NOB}$ and $\mathrm{AOB}$ at a ratio of 1.72-5.87 may cause ammonia uptake of $3.25 \pm$ $0.52 \mathrm{mg} \mathrm{NH}_{4}{ }^{+}-\mathrm{N}(\mathrm{g} \mathrm{VSS})^{-1} \cdot \mathrm{h}^{-1}$ and nitrite uptake of 4.49 $\pm 0.49 \mathrm{mg} \mathrm{NO}{ }_{2}^{-}-\mathrm{N}\left(\mathrm{g} \mathrm{VSS}^{-1} \cdot \mathrm{h}^{-1}\right.$ and are efficient for nutrient removal in wastewater treatment plant (Yao and Peng, 2017).

Chemoautotrophic nitrifying bacteria have a very slow growth rate, and that is why they hardly form biofilms. Nitrifiers having high biofilm-forming capacity can be used for the treatment of ammonia polluted aquaculture water. Different strains of Nitrosococcus and Nitrosomonas are efficient for ammonia removal (Hoang et al., 2016). Probiotics formed by Nitrosomonas and Nitrobacter are beneficial for ammonia removal in shrimp (Litopenaeus vannamei) culture (Karthik et al., 2015). Several studies have been done about the uses of nitrifying bacteria. Hence the enhancement of the activity of nitrifying bacteria within their natural system without introducing them form outside needs special attention.

Weisany et al. (2013) have mentioned the role of some micronutrients in the enhancement of the nitrification process. However, some of those micronutrients are also essential for fish growth. Application of cobalt in the form of $\mathrm{CoCl}_{2}$ at a dose of $10 \mathrm{~kg} . \mathrm{ha}^{-1}$ significantly increases primary productivity, Chlorophyll a production, plankton volume and growth of Labeo rohita (Hamilton, 1822) (Adhikari and Ayyappan, 2002). Cobalt is an important micronutrient 
for fish growth, and at the same time, it is essential for nitrogen-fixing microorganisms, including cyanobacteria. Zinc is an essential nutrient because of its catalytic function over 300 proteins which greatly enhances fish growth, reproduction and development (Terech-Majewska et al., 2016) and at the same time also have a role in nitrogen fixation. Similarly, many other nutrients such as iron and copper also play a dual role both in enhancing fish growth and nitrogen cycle. So the application of these micronutrients to enhance the abundance of nitrifying bacteria will give a new dimension for increasing the productivity of the aquatic system as well as minimise $\mathrm{N}_{2} \mathrm{O}$ emission by continuous uptake of nitrogen by the primary producers.

\section{Conclusion}

Nitrogen, as different species of dissolved inorganic nitrogen consisting of $\mathrm{NH}_{4}-\mathrm{N}, \mathrm{NO}_{2}-\mathrm{N}$ and $\mathrm{NO}_{3}-\mathrm{N}$, plays an important role in fish pond productivity. Variability of these inorganic forms of nitrogen along with other nutrients determines the water quality and pond productivity, thereby composition and abundance of flora and fauna. Various microbial decomposers are responsible for the conversion of organic matter and mineralisation of organic $\mathrm{N}$ into inorganic forms. The abundance of the nitrifiers is highly correlated with phytoplankton productivity as it prefers to use nitrogen in the form of nitrate. The potentiality of surplus nitrogen removal by DNB produces opportunities for the management of the nitrogen cycle in ponds. The nitrogen cycle is also affected by seasonal variations of $\mathrm{O}_{2}$ penetration, $\mathrm{pH}$, water exchange, aeration and circulation. Different methods have been proposed by the researchers to avoid nitrogen toxicity in fish farming ponds, thereby maintaining the pond water conducive for fish growth. Moreover, the usage of nitrifiers (viz. AOB, NOB) in the form of biofilm also enhances the productivity of the aquatic ecosystem. Application of system-specific suitable methods for utilisation of different nitrogen cycle bacteria will increase the efficiency of organic matter recycling for fish growth as well as reduces the emission of $\mathrm{N}_{2} \mathrm{O}$. Therefore, further studies are needed to enhance the nitrogen mineralisation by avoiding its toxicity and getting optimum available $\mathrm{N}$ nutrients for increasing fish growth and production in organic fish culture systems considering economic feasibility of the culture methods and the environment.

\section{Acknowledgements}

This work was supported by the Grant (vide F. No. 890 (Sanc.)/ST/P/S\&T/1G-1/2013 Dt. 15.01.2016) from the Department of Science, Technology \& Biotechnology (DSTB), Government of West Bengal, Kolkata (to SD). Authors are thankful to Dr. Sovon Roy, Department of Science, Technology \& Biotechnology, Govt. of West Bengal for his continuous encouragement. Authors are also thankful to Dr. Debraj Biswal, Assistant
Professor of Zoology, WBES, Govt. of West Bengal, for his special contribution in language editing during revision of the manuscript. The authors are grateful to the anonymous reviewers and the editorial team of Asian Fisheries Science for their constructive comments and continuous efforts in improving the clarity and quality of the manuscript.

\section{References}

Abeliovich, A. 2006. The nitrite oxidizing bacteria. In: Prokaryotes, Dworkin, M., Falkow, S., Rosenberg, E., Schleifer, K.H., Stackebrandt, E. (Eds.), Springer, New York, pp. 861-872. https://doi.org/10.1007/0-387-30745-1_41

Abraham, T.J., Ghosh, S., Nagesh, T.S., Sasmal, D. 2004. Distribution of bacteria involved in nitrogen and sulphur cycles in shrimp culture systems of West Bengal, India. Aquaculture 239:275-288. https://doi.org/10.1016/j.aquaculture.2004.06.023

Adhikari, S., Ayyappan, S. 2002. Fertilisation of freshwater fish ponds with cobalt and its adsorption and desorption in the pond sediment. The Israeli Journal of Aquaculture - Bamidgeh 54:110-115.

Ahn, J.H., Kim, S., Park, H., Rahm, B., Pagilla, K., Chandran, K. 2010. N2O emissions from activated sludge processes, 2008-2009: results of a national monitoring survey in the United States. Environmental Science \& Technology 44:4505-4511. https://doi.org/10.1021 les903845y

Alexander, M. 1978. Introduction to soil microbiology. $2^{\text {nd }}$ Edition. Wiley Eastern Limited, New Delhi. 467 pp.

Allison, S.M., Prosser, J.I. 1991. Urease activity in neutrophilic autotrophic ammonia-oxidizing bacteria isolated from acid soils. Soil Biology and Biochemistry 23:45-51. https://doi.org/10.1016/00380717(91)90161-C

Anderson, G.R. 1955. Nitrogen fixing by Pseudomonas like soil bacteria. Journal of Bacteriology 70:129-133. https://doi.org/10.1128 /JB.70.2.129-133.1955

Axler, R.P., Redfield, G.W., Goldman, C.R. 1981. The importance of regenerated nitrogen to phytoplankton productivity in a subalpine lake. Ecology 62:345-354. https://doi.org/10.2307/1936709

Banerjea, S.M. 1967. Water quality and soil conditions of fish ponds in some states of India in relation to fish production. Indian Journal of Fisheries 14:115-144.

Bardon, C., Poly, F., Piola, F., Pancton, M., Comte, G., Meiffren, G., Haichar, F.E.Z. 2016. Mechanism of biological denitrification inhibition: procyanidins induce an allosteric transition of the membrane-bound nitrate reductase through membrane alteration. FEMS Microbiology Ecology 92:1-11. https://doi.org /10.1093/femsec/fiw034

Barik, P., Ram, R., Haldar, C., Vardia, H.K. 2018. Study on nitrifying bacteria as bioremediator of ammonia in simulated aquaculture system. Journal of Entomology and Zoology Studies 6:1200-1206.

Bhakta, J.N., Bandyopadhyay, P.K., Jana, B.B. 2006. Effect of different doses of mixed sfertiliser on some biogeochemical cycling bacterial population in carp culture pond. Turkish Journal of Fisheries and Aquatic Sciences 6:165-171.

Bianchi, M., Bonin, P., Feliatra, F. 1994. Bacterial nitrification and denitrification rates in the Rhone River plume (Northwestern Mediterranean Sea). Marine Ecology Progress Series 103:197-202. https://doi.org/10.3354/meps103197

Blackburn, T.H., Lund, B.A., Krom, M.D. 1988. C-and N-mineralization in the sediments of earthen marine fish ponds. Marine Ecology Progress Series 44:221-227. https://doi.org/10.3354/meps044221

Botan, E.A., Miller, J.J., Kleerekoper, H. 1960. A study of the 
microbiological decomposition of nitrogenous matter in fresh water. Archiv fur Hydrobiologie 56:334-353.

Bothe, H., Jost, G., Schloter, M., Ward, B.B., Witzel, K.P. 2000. Molecular analysis of ammonia oxidation and denitrifcation in natural environments. FEMS Microbiology Reviews 24:673-690. https://doi.org/10.1111/j.1574-6976.2000.tb00566.x

Brezonik, P.L. 1972. Nitrogen: Sources and transformation in natural waters. In: Nutrients in natural waters, Allen, H.E., Kramer, J.R. (Eds.), Wiley-Interscience Publications, New York, pp. I-50.

Burford, M.A., Longmore, A.R. 2001. High ammonium production from sediments in hypereutrophic shrimp ponds. Marine Ecology Progress Series 224:187-195. https://doi.org/10.3354/meps224187

Burrell, P.C., Phalen, C.M., Hovanec, T.A. 2001. Identification of bacteria responsible for ammonia oxidation in freshwater aquaria. Applied and Environmental Microbiology 67:5791-5800. https://doi.org /10.1128/AEM.67.12.5791-5800.2001

Camargo Valero, M.A., Mara, D.D. 2010. Ammonia volatilisation in waste stabilisation ponds: a cascade of misinterpretations? Water Science and Technology 61:555-561. https://doi.org/10.2166/wst.2010.856

Camargo, J.A., Alonso, A., Salamanca, A. 2005. Nitrate toxicity to aquatic animals: a review with new data for freshwater invertebrates. Chemosphere 58:1255-1267. https://doi.org/10.1016 /j.chemosphere.2004.10.044

Cavari, B.Z. 1977. Nitrification potential and factors governing the rate of nitrification in Lake Kinneret. Oikos 28:285-290. https://doi.org $\underline{110.2307 / 3543983}$

Chen, Z., Liu, J., Wu, M., Xie, X., Wu, J., Wei, W. 2011. Differentiated response of denitrifying communities to sfertilisation regime in paddy soil. Microbial Ecology 63:446-459. https://doi.org/10.1007 /s00248-011-9909-5

Christman, G.D., Cottrell, M.T., Popp, B.N., Gier, E., Kirchman, D.L. 2011. Abundance, diversity, and activity of ammonia-oxidizing prokaryotes in the coastal Arctic Ocean in summer and winter. Applied and Environmental Microbiology 77:2026-2034. https://doi.org.10.1128 IAEM.01907-10

Covich, A.P., Palmer, M.A., Crowl, T.A. 1999. The role of benthic invertebrate species in freshwater ecosystems: zoobenthic species influence energy flows and nutrient cycling. Bio Science 49:119-127. https://doi.org/10.2307/1313537

Crab, R., Avnimelech, Y., Defoirdt, T., Bossier, P., Verstraete, W. 2007. Nitrogen removal techniques in aquaculture for a sustainable production. Aquaculture 270:1-14. https://doi.org/10.1016 /j.aquaculture.2007.05.006

Daims, H., Lücker, S., Wagner, M. 2016. A new perspective on microbes formerly known as nitrite-oxidizing bacteria. Trends in Microbiology 24:699-712. https://doi.org/10.1016/j.tim.2016.05.004

Diab, S., Kochba, M., Avnimelech, Y. 1993. Nitrification pattern in a fluctuating anaerobic-aerobic pond environment. Water Research 27:1469-1475. https://doi.org/10.1016/0043-1354(93)90027-F

Diab, S., Shilo, M. 1986. Transformation of nitrogen in sediments of fish ponds in Israel. The Israeli Journal of Aquaculture - Bamidgeh 38:6788.

Dong, L.F., Smith, C.J., Papaspyrou, S., Stott, A., Osborn, A.M., Nedwell, D.B. 2009. Changes in benthic denitrification, nitrate ammonification, and anammox process rates and nitrate and nitrite reductase gene abundances along an estuarine nutrient gradient (The Colne Estuary, United Kingdom). Applied and Environmental Microbiology 75:3171-3179. https://doi.org/10.1128/AEM.02511-08

Dvir, O., van Rijn, J., Neori, A. 1999. Nitrogen transformations and factors leading to nitrite accumulation in a hypertrophic marine fish culture system. Marine Ecology Progress Series 181:97-106. https://doi.org/10.3354/meps181097
Eddy, F.B., Williams, E.M. 1987. Nitrite and freshwater fish. Chemistry and Ecology 3:1-38. https://doi.org/10.1080/02757548708070832

Fečkaninová, A., Koščová, J., Mudroňová, D., Popelka, P., Toropilova, J. 2017. The use of probiotic bacteria against Aeromonas infections in salmonid aquaculture. Aquaculture 469:1-8. https://doi.org/10.1016 /j.aquaculture.2016.11.042

Feliatra, F. 2001. Activity of nitrifying bacteria (ammonia soxidiser and nitrite oxidiser) in brackishwater ponds (tambak) in Bengkalis Island, Riau Province. Journal of Coastal Zone Management 4:51-62.

Feliatra, F. 2003. Role of nitrifying bacteria in purification process of brackishwater ponds (Tambak) in Riau Province Indonesia. Journal Nature Indonesia 5:133-138.

Feliatra, F., Bianchi, M. 1993. Rates of nitrification and carbon uptake in the Rhone river plume (Nothwestern Mediterranean Sea). Microbial Ecology 26:21-28. https://doi.org/10.1007/BF00166026

Fernandes, S.O., Kulkarni, S.S., Shirodkar, R.R., Karekar, S.V., Kumar, R.P., Sreepada, R.A., Vogelsang, C., LokaBharathi, P.A. 2010. Water quality and bacteriology in an aquaculture facility equipped with a new aeration system. Environmental Monitoring and Assessment 164:81-92. https://doi.org/10.1007/s10661-009-0876-y

Fernandez, L., Bertilsson, S., Peura, S. 2020. Non-cyanobacterial diazotrophs dominate nitrogen-fixing communities in permafrost thaw ponds. Limnology and Oceanography 65:S180-\$193. https://doi.org/10.1002/Ino.11243

Gołaś, I., Zmysłowska, I., Harnisz, M., Korzekwa, K., Skowrońska, A., Teodorowicz, M., Górniak, D., Gros, M., Brzozowa, S. 2008. Nitrogen cycle bacteria in the waters of the river Drwęca. Polish Journal of Environmental Studies 17:215-225.

Gregory, R.B. 1977. Synthesis and total excretion of waste nitrogen by fish of the periophthalmus (mudskipper) and scartelaos families. Comparative Biochemistry and Physiology part A: Physiology 57:3336. https://doi.org/10.1016/0300-9629(77)90344-9

Guerin-Ancy, 0. 1976. Experimental study of the nitrogen excretion of bass (Dicentrarchus labrase) during growth, 1: Effects of temperature and weight on excretion of ammonia and urea. Aquaculture 9:71-80. https://doi.org/10.1016/0044-8486(76)90049-1

Hargreaves, J.A. 1995. Nitrogen biochemistry of aquaculture pond sediments. Ph.D. dissertation. Louisiana State University, LA., USA. $241 \mathrm{pp}$.

Hargreaves, J.A. 1998. Nitrogen biogeochemistry of aquaculture ponds. Aquaculture 166:181-212. https://doi.org/10.1016/S00448486(98)00298-1

Hargreaves, J.A., Tucker, C.S. 2004. Managing ammonia in fish ponds. Southern Regional Aquaculture Center Publication No. 4603.8 pp.

Hasan, B.M.A., Guha, B., Datta, S. 2012. Efficacy of probiotics on growth and sustainable production of black tiger shrimp, Penaeus monodon Fabricius 1798 in brackishwater ponds of West Bengal, India. Asian Fisheries Science 25:303-316.

Herbert, R.A., 1999. Nitrogen cycling in coastal marine ecosystems. FEMS Microbiology Reviews 23:563-590. https://doi.org/10.1111/j.1574-6976.1999.tb00414.X

Hoang, P.H., Nguyen, H.T., Tran, T.T., Tran, T.T., Do, L.P., Le, T.N.C. 2016. Isolation and selection of nitrifying bacteria with high biofilm formation for treatment of ammonium polluted aquaculture water. Journal of Vietnamese Environment 8:33-40.

Hopkinson, C.S., Giblin, A.E. 2008. Nitrogen dynamics of coastal salt marshes. In: Nitrogen in the marine environment, $2^{\text {nd }}$ Edition, Capone, D., Bronk, D., Mulholland, M., Carpenter, E. (Eds.), Academic Press, USA, pp. 991-1036. https://doi.org/10.1016/B978-0-12-372522$\underline{6.00022-0}$

Hovanec, T.A., DeLong, E.F. 1996. Comparative analysis of nitrifying bacteria associated with freshwater and marine aquaria. Applied and 
Environmental Microbiology 62:2888-2896. https://doi.org 110.1128/AEM.62.8.2888-2896.1996

Isobe, K., Ohte, N. 2014. Ecological perspectives on microbes involved in $\mathrm{N}$-cycling. Microbes and Environments 29:4-16. https://doi.org /10.1264/jsme2.ME13159

Jana, B.B., Chakraborty, P., Biswas, J.K., Ganguly, S. 2001(b). Biogeochemical cycling bacteria as indices of pond fertilisation: importance of CNP ratios of input fertilisers. Journal of Applied Microbiology 90:733-740. https://doi.org/10.1046/j.1365$\underline{\text { 2672.2001.01299.x }}$

Jana, B.B., Chatterjee, J., Ganguly, S., Jana, T. 2001(a). Responses of phosphate ssolubilising bacteria to qualitatively different sfertilisation in simulated and natural fish ponds. Aquaculture International 9:17-34. https://doi.org/10.1023/A:1012594828876

Jana, B.B., Chatterjee, J., Jana, T.K. 1997. Dose dependent interactions between ammonification potential and bacteria in three tropical pond ecosystems. Chemistry and Ecology 13:139-154. https://doi.org/10.1080/02757549708038547

Jana, B.B., Patel, G.N. 1985. Distribution pattern of denitrifying bacteria in fish ponds of differing farming managements. Archiv fur Hydrobiologie 103:291-303.

Jana, B.B., Roy, S.K. 1985(a). Spatial and temporal changes of nitrifying bacterial populations in fish ponds of differing management practices. Journal of Applied Bacteriology 59:195-204. https://doi.org/10.1111/j.1365-2672.1985.tb03321.x

Jana, B.B., Roy, S.K. 1985(b). Distribution patterns of protein mineralising and ammonifying bacterial populations in fish-farming ponds under different management systems. Aquaculture 44:57-65. https://doi.org/10.1016/0044-8486(85)90042-0

Jana, B.B., Roy, S.K. 1986. Seasonal and spatial distribution pattern of nitrogen fixing bacteria in fish ponds under different management systems. Hydrobiologia 137:45-54. https://doi.org /10.1007/BF00004171

Jiao, Y., Jin, W.B., Zhao, Q.L., Zhang, G.D., Yan, Y., Wan, J. 2009. Transformation of nitrogen and distribution of nitrogen-related bacteria in a polluted urban stream. Water Science and Technology 60:1597-1605. https://doi.org/10.2166/wst.2009.502

Jiménez-Ojeda, Y.K., Collazos-Lasso, L.F., Arias-Castellanos, J.A. 2018. Dynamics and use of nitrogen in Biofloc Technology-BFT. AACL Bioflux 11:1107-1129.

Jones, J.G., Simon, B.M. 1981. Differences in microbial decomposition processes in profundal and littoral lake sediments, with particular reference to the nitrogen cycle. Microbiology 123:297-312. https://doi.org/10.1099/00221287-123-2-297

Karthik, R., Pushpam, A.C., Chelvan, Y., Vanitha, M.C. 2015. Efficacy of probiotic and nitrifier bacterial consortium for the enhancement of Litopenaeus vannamei aquaculture. International Journal of Veterinary Science and Research 1:029-034. https://doi.org $\underline{110.17352 / \mathrm{ijvsr} .000006}$

Kathiravan, V., Krishnani, K.K. 2014. Diversity of denitrifying bacteria in the green water system of coastal aquaculture. International Aquatic Research 6:135-145. https://doi.org/10.1007/s40071-014-0074-6

Kim, W.K., Cui, R., Jahn, D. 2005. Enrichment of ammonia-oxidizing bacteria for efficient nitrification of wastewater. Journal of Microbiology and Biotechnology 15:772-779.

Krishnani, K.K., Kathiravan, V. 2015. Functional gene based multiplex PCR to detect bacteria implicated in biotransformation of nitrogen, sulfur and methane in aquatic environment. Indian Journal of Biotechnology 14:482-488.

Krishnani, K.K., Shekhar, M.S., Gopikrishna, G., Gupta, B.P. 2009. Sequence similarity based identification of nitrifying bacteria in coastal aquaculture for bioremediation predictability. Asian Fisheries Science 22:41-49.

Kristensen, E., Ahmed, S.I., Devol, A.H. 1995. Aerobic and anaerobic decomposition of organic matter in marine sediment: which is fastest? Limnology and Oceanography 40:1430-1437.

https://doi.org/10.4319/lo.1995.40.8.1430

Kroupova, H., Machova, J., Svobodova, Z. 2005. Nitrite influence on fish: a review. Veterinarni Medicina 50:461-471. https://doi.org /10.17221/5650-VETMED

Kumari, V., Rathore, G., Chauhan, U.K., Pandey, A.K., Lakra, W.S. 2011. Seasonal variations in abundance of nitrifying bacteria in fish pond ecosystem. Journal of Environmental Biology 32:153-159.

Kuznetsov, S.I. 1970. Microflora of lakes and their geochemical activities. Izdatel'Stvo Naudaka, Leningrad. 440 pp.

Limpiyakorn, T., Shinohara, Y., Kurisu, F., Yagi, 0. 2005. Communities of ammonia-oxidizing bacteria in activated sludge of various sewage treatment plants in Tokyo. FEMS Microbiology Ecology 54:205-217. https://doi.org/10.1016/j.femsec.2005.03.017

Lu, S., Liao, M., Xie, C., He, X., Li, D., He, L., Chen, J. 2015. Seasonal dynamics of ammonia-oxidizing microorganisms in freshwater aquaculture ponds. Annals of Microbiology 65:651-657. https://doi.org/10.1007/s13213-014-0903-2

Mahanta, D., Jena, J.K., Das, B.K. 2014. Evaluation and efficacy study of nitrifying bacteria in freshwater aquaculture system. International Journal of Current Microbiology and Applied Sciences 3:962-969.

McCarthy, J.J. 1981. The kinetics of nutrient utilisation. In: Physiological bases of phytoplankton ecology Platt, T.J. (Ed.), Canadian Fisheries Research Board Bulletin 210, Ottawa, Canada, pp. 211-233.

Mlejnkova, H., Sovova, K. 2012. Impact of fish pond manuring on microbial water quality. Acta Universitatis Agriculturae Et Silviculturae Mendelianae Brunensis 60:117-124. https://doi.org /10.11118/actaun201260030117

Montgomery, R.T., McPherson, B.F., Emmons, E.E. 1991. Effects of nitrogen and phosphorus additions on phytoplankton productivity and chlorophyll a in a subtropical estuary, Charlotte Harbor Florida. Water-Resources Investigations Report 91:4077.

Montuelle, B., Kestemont, P., Chalamet, A. 1992. Kinetics of amino acids smineralisation by a pond sediment bacterial community. Hydrobiologia 243/244:71-77. https://doi.org/10.1007/BF00007021

Morii, H., Nishikata, K., Tamura, O. 1978. Nitrogen excretion of mudskipper fish Periophthalmus cantonensis and Boleophthalmus pectinirostris in water and on land. Comparative Biochemistry and Physiology Part A: Physiology 60A:189-193. https://doi.org /10.1016/0300-9629(78)90229-3

Mulder, E.G. 1975. Physiology and ecology of free-living, nitrogen-fixing bacteria. In: Nitrogen fixation by free-living micro-organisms Steward, W.D.P.(Ed.), Cambridge University Press, London, pp.1-27.

Niewolak, S. 1972. Fixation of atmospheric nitrogen by Azotobacter sp. and other heterotrophic oligonitrophilous bacteria in the llawa lakes. Acta Hydrobiologica 14:287-305.

Oribhabor, B.J., Ansa, E.J. 2006. Organic waste reclamation, recycling and re-use in integrated fish farming in the Niger Delta. Journal of Applied Sciences and Environmental Management 10:47-53. https://doi.org/10.4314/jasem.v10i3.17319

Pandey, P.K., Sreelu, N.S. 2006. Nitrogen-fixing aerobic bacteria and their nitrogenase activity in north Mumbai coastal waters. Journal of the Indian Fisheries Association 33:95-102.

Prosser, J.I. 2005. Nitrification. In: The encyclopedia of soils in the environment, vol. 3, Hillel, D., Hatfield, J.L. (Eds.), Elsevier, Oxford, pp. 31-39. https://doi.org/10.1016/B0-12-348530-4/00512-9 
Qin,Y., Hou, J., Deng, M., Liu, O., Wu, C., Ji, Y., He, X. 2016. Bacterial abundance and diversity in pond water supplied with different feeds. Scientific Reports 6:35232. https://doi.org/10.1038/srep35232

Rathsack, K., Böllmann, J., Martienssen, M. 2014. Comparative study of different methods for sanalysing denitrifying bacteria in fresh water ecosystems. Journal of Water Resource and Protection 6:609. https://doi.org/10.4236/jwarp.2014.66059

Richared, P.A., John, E.R. 1996. Nitrate uptake by phytoplankton and periphyton: Whole-lake enrichments and mesocosm- ${ }^{15} \mathrm{~N}$ experiments in an oligotrophic lake. Limnology and Oceanography 41:659-671. https://doi.org/10.4319//0.1996.41.4.0659

Rysgaard, S., Risgaard-Petersen, N., Niels Peter, S., Kim, J., Lars Peter, N. 1994. Oxygen regulation of nitrification and dentrificication in sediments. Limnology and Oceanography 39:1643-1652. https://doi.org/10.4319/lo.1994.39.7.1643

Rysgaard, S., Risgaard-Petersen, N., Nielsen, L.P., Revsbech, N.P. 1993. Nitrification and denitrification in lake and estuarine sediments measured by the ${ }^{15} \mathrm{~N}$ dilution technique and isotope pairing. Applied Environmental Microbiology 59:2093-2098. https://doi.org/10.1128 IAEM.59.7.2093-2098.1993

Santos, N.B.V.D., Furtado, P.S., Cesar, D.E., Wasielesky, W. 2019. Assessment of the nitrification process in a culture of pacific white shrimp, using artificial substrate and bacterial inoculum in a biofloc technology system (BFT). Ciência Rural 49:e20180306 https://doi.org/10.1590/0103-8478cr20180306

Sepers, A.B.J. 1981. Diversity of ammonifying bacteria. Hydrobiologia 83:343-350. https://doi.org/10.1007/BF00008285

Serezli, R., Kucukagtas, R.A., Kurtoglu, I.Z. 2016. Acute toxicity of ammonia and nitrite to angel fish (Pterophyllum scalare, Liechtenstein 1823) and the effect of erythrocyte morphology. Fresenius Environmental Bulletin 25:3119-3124.

Shan, H., Obbard, J.P. 2003. Ammonia removal from freshwater using nitrifying bacteria enriched from a seawater aquaculture pond. Biotechnology Letters 25:1469-1471. https://doi.org /10.1023/A:1025028222609

Shilo, M., Rimon, A. 1982. Factors which affect the intensification of fish breeding in Israel: 2. Ammonia transformation in intensive fish ponds. The Israeli Journal of Aquaculture - Bamidgeh 34:101-114.

Siripong, S., Kelly, J.J., Stahl, D.A., Rittmann, B.E. 2006. Impact of sprehybridisation PCR amplification on microarray detection of nitrifying bacteria in wastewater treatment plant samples. Environmental Microbiology 8:1564-74. https://doi.org/10.1111/j.14622920.2006.01047.x

Smith, T.M., Smith, R.L. 2006. Elements of ecology. $6^{\text {th }}$ Edition. Pearson Benjamin Cummings, San Francisco. 658 pp.

Sousa, T., Ingole, B., Sousa, S., Bhosle, S. 2013. Seasonal variations of nitrate reducing and denitrifying bacteria utilising hexadecane in Mandovi estuary, Goa, West Coast of India. Indian Journal of Geomarine Sciences 42:587-592.

Sprent, J.I., 1979. The biology of nitrogen-fixing organisms. McGraw-Hill Book Co. Ltd, UK, pp. 13-196.

Stefanakis, A., Akratos, C.S., Tsihrintzis, V.A. 2014. Modeling of vertical flow constructed wetlands. In: Vertical flow constructed wetlands: eco-engineering systems for wastewater and sludge treatment. Elsevier, Amsterdam. 392 pp. https://doi.org/10.1016/B978-0-12404612-2.00008-8

Stief, P. 2013. Stimulation of microbial nitrogen cycling in aquatic ecosystems by benthic macrofauna: mechanisms and environmental implications. Biogeosciences 10:7829-7846. https://doi.org/10.5194/bg-10-7829-2013

Sudthikaran, Y., Kantachote, D., Wittayaweerasak, B. 2007. Impacts of intensive shrimp cultivation on bacteria in the nitrogen cycle and physicochemical properties of sediments. Songklanakarin Journal of Science and Technology 29:25-35.

Syrett, P.J. 1981. Nitrogen metabolism of microalgae. In: Physiological bases of phytoplankton ecology, Platt, T.J. (Ed.), Canadian Fisheries Research Board Bulletin 210, Ottawa, Canada, pp. 182-210.

Terech-Majewska, E., Pajdak, J., Siwicki, A.K. 2016. Water as a source of macronutrients and micronutrients for fish with special emphasis on the nutritional requirements of two fish species: the common carp (Cyprinus carpio) and the rainbow trout (Oncorhynchus mykiss). Journal of Elementology 21:947-961. https://doi.org/10.5601 /jelem.2015.20.4.940

van Kessel, J.F. 1977. Factors affecting the denitrification rate in two water-sediment systems. Water Research 11:259-267. https://doi.org/10.1016/0043-1354(77)90057-4

van Rijn, J. 1996. The potential for integrated biological treatment systems in recirculating fish culture- a review. Aquaculture 139:181201. https://doi.org/10.1016/0044-8486(95)01151-X

van Rijn, J., Diab, S. and Shilo, M., 1984. Mechanisms of ammonia transformations in fish ponds. In: Research on aquaculture, Rosenthal, H. and S. Sarig (Eds.), Special Publication No. 8, European Mariculture Society, Bredene, Belgium, pp. 17-40.

van Rijn, J., Tal, Y., Schreier, H.J. 2006. Denitrification in recirculating systems: Theory and applications. Aquaculture Engineering 34:364376. https://doi.org/10.1016/j.aquaeng.2005.04.004

Vass, K.K., Chattopadhyay, G.N., Adhikari, S., Datta, S., Samanta, S. 2017. Assessment of nitrogen in freshwater aquaculture in India. In: The Indian nitrogen assessment, Abrol, Y.P., Adhya, T.K., Aneja, V.P. Raghuram, N., Pathak, H., Kulshrestha, U., Sharma, C., Singh, B. (Eds.), Elsevier, pp. 267-286. https://doi.org/10.1016/B978-0-12811836-8.00018-5

Wada, E., Hattori, A. 1971. Nitrite metabolism in the euphotic layer of the central North Pacific Ocean. Limnology and Oceanography 16:766772. https://doi.org/10.4319/lo.1971.16.5.0766

Wallace, R.A., Saunders, G.P., Ferl, R.J. 1991. Biology: The science of life. $3^{\text {rd }}$ Edition. Harper Collins, New York. 44 pp.

Weisany, W., Raei, Y., Allahverdipoor, K.H. 2013. Role of some of mineral nutrients in biological nitrogen fixation. Bulletin of Environment, Pharmacology and Life Sciences 2:77-84.

Wielgosz, E., Jóźwiakowski, K., Bielińska, E.J. 2010. Numbers of ammonifying, nitrifying and denitrifying bacteria in sewage treated in a system of biological stabilisation ponds. Teka Komisji Ochrony i Kształtowania Środowiska Przyrodniczego 7:446-456.

Wongkiew, S., Hu, Z., Chandran, K., Lee, J.W. and Khanal, S.K., 2017. Nitrogen transformations in aquaponic systems: A review. Aquacultural Engineering 76:9-19. https://doi.org/10.1016 /j.aquaeng.2017.01.004

Wrage, N., Velthof, G.L., Van Beusichem, M.L., Oenema, O., 2001. Role of nitrifier denitrification in the production of nitrous oxide. Soil Biology and Biochemistry33:1723-1732. https://doi.org/10.1016 IS0038-0717(01)00096-7

Wright, P.A., Land, M.D. 1998. Urea production and transport in teleost fishes. Comparative Biochemistry and Physiology Part A: Molecular \& Integrative Physiology 119:47-54. https://doi.org/10.1016/S10956433(97)00407-8

Yadav, R.C. 2014. Biological nitrogen harvesting from aquatic ecosystems-a new scientific vision. Fisheries and Aquaculture Journal 5:1-8. https://dx.doi.org/10.4172/2150-3508.1000100

Yao, O., Peng, D.C. 2017. Nitrite oxidizing bacteria (NOB) dominating in nitrifying community in full-scale biological nutrient removal wastewater treatment plants. AMB Express 7:25. https://doi.org /10.1186/s13568-017-0328-y 
Yool, A. 2011. Modeling the role of nitrification in open ocean productivity and the nitrogen cycle. In: Methods in enzymology, vol. 486, Klotz, M.G. (Ed.), Elsevier Academic Press, San Diego, pp. 3-32. https://doi.org/10.1016/B978-0-12-381294-0.00001-8

Yoshinari, T., Hynes, R., Knowles, R. 1977. Acetylene inhibition of nitrous oxide reduction and measurement of denitrification and nitrogen fixation in soil. Soil Biology and Biochemistry 9:177-183. https://doi.org/10.1016/0038-0717(77)90072-4

Zhao, X., Wei, Z., Zhao, Y., Xi, B., Wang, X., Zhao, T., Zhang, X., Wei, Y. 2015. Environmental factors influencing the distribution of ammonifying and denitrifying bacteria and water qualities in 10 lakes and reservoirs of the Northeast, China: Distribution of $A B$ and DNB. Microbial Biotechnology 8:541-548. https://doi.org/10.1111/17517915.12260

Zheng, Y., Harris, D.F., Yu, Z., Fu, Y., Poudel, S., Ledbetter, R.N., Fixen, K.R., Yang, Z.Y., Boyd, E.S., Lidstrom, M.E., Seefeldt, L.C. 2018. A pathway for biological methane production using bacterial iron-only nitrogenase. Nature Microbiology 3:281-286. https://doi.org /10.1038/s41564-017-0091-5

Zhou, L. and C.E. Boyd. 2015. Ammonia nitrogen management in aquaculture ponds. Aquaculture Magazine (October-November) 41:18-21. 